\title{
PENGEMBANGAN PERMAINAN MAHKOTA BERTEMAN UNTUK PEMBELAJARAN MENGENALKAN KONSEP DAN LAMBANG BILANGAN PADA ANAK USIA DINI
}

\author{
Ayu Asmah \\ Prodi PG-PAUD, Fakultas Ilmu Pendidikan, Universitas Kanjuruhan Malang \\ ayuasmah@unikama.ac.id \\ Tri Candra Wulandari \\ Prodi Matematika, Fakultas Sains dan Teknologi, Universitas Kanjuruhan Malang \\ fikri_chan@yahoo.com
}

\begin{abstract}
Games for growing and developing early childhood provides opportunity to be able to explore and interact with the surrounding environment. A good game form for early childhood is an educative game, a game that stimulates the child's thinking power and helps to optimize aspects of his development. The phenomenon of learning in early childhood at this time is more directed to the academic, so the principle of learning while playing is replaced with worksheets. The purpose of this study is to produce a suitable game of mahkota berteman to be used for learning to introduce concepts and symbols of numbers in early childhood, and improve the ability of early childhood in recognizing the concept and symbol of numbers. The study was conducted in ten stages according to Dick and Carey's Development Research theory (2011), (1) Identity Instructional Goal, (2) Conduct Instructional Analysis, (3) Analyze Learners and Contexts, (4) Write Performance Objectives, (5) Develop Assessment Instrumens, (6) Develop Instructional Strategy, (7) Develop and Select Instructional Materials, (8) Design and Conduct Formative Evaluation of Instruction, (9) Revise Instruction, (10) Design And Conduct Summative Evaluation. The results showed that mahkota berteman gamers were eligible for learning to introduce the concept and symbol of numbers in early childhood. Based on the data analysis of field test results using $\mathrm{T}$ test shows that the significance obtained by 0.000 is smaller on the significance used in this research that is 0,05 ( $\mathrm{sig}=0,000<0,05)$, thus $\mathrm{H} 0$ is rejected and $\mathrm{H} 1$ accepted. So the result this development research can be concluded that after using the mahkota berteman game befriending the ability of children in knowing the concept and the symbol of numbers to be better.
\end{abstract}

Keywords: games, mahkota berteman, concepts and number symbols

\section{PENDAHULUAN}

Pendidikan bagi anak usia dini merupakan pendidikan yang diberikan melalui pemberian kesempatan bagi anak untuk dapat menikmati dunianya, yaitu dunia main. Bermain menjadi sarana bagi anak untuk belajar, sehingga belajar bagi anak usia dini adalah bermain. Berdasarkan hal tersebut, bentuk pemberian stimulasi bagi anak usia dini dilakukan dengan menyediakan wahana bermain untuk anak-anak.

Menurut Hoorn, dkk. (dalam Musfiroh, 2005: 13) bermain merupakan landasan bagi perkembangan karena bagian dari perkembangan sekaligus sumber energi perkembangan itu sendiri. Bermain itu sendiri memiliki kekuatan 
untu menggerakkan perkembangan anak.

Permainan memberikan kesempatan dan kebebasan pada anak usia dini untuk berimajinasi, menggali potensi, menyalurkan minat, berkreativitas dan bereksplorasi. Permainan bagi anak usia dini diarahkan untuk merangsang pertumbuhan dan perkembangan, sehingga dibutuhkan peranan pendidik atau orang tua untuk dapat mendukungnya melalui bentukbentuk permainan yang sesuai dengan kebutuhannya. Hal ini sesuai dengan pendapat Hurlock (dalam Susanto, 2012: 50) menyebutkan bahwa anak dalam rentang usia 3-5 tahun adalah masa permainan.

Pemberian pengalaman belajar pada anak usia dini terhadap konsepkonsep dilakukan secara konkret, peragaan langsung, dan dikemas melalui kegiatan bermain. Melalui cara ini, secara tidak langsung anak dapat menerima apa yang diajarkan atau dikenalkan kepadanya. Karena disaat mereka melakukan kegiatan bermain, saat itulah proses belajar terhadap suatu obyek dilakukan. Keaktifan yang dilakukan mendukung proses penerimaan pengetahuan secara langsung.

Aktivitas bermain bagi anak merupakan pemberian kesempatan untuk membangun dunianya, berinteraksi dengan orang lain dalam lingkungan sosial, mengekspresikan dan mengontrol emosinya, serta mengembangkan kecakapan simboliknya (Musfiroh, 2005: 36). Secara tidak langsung guru harus dapat merancang kegiatan pembelajaran yang memiliki ciri-ciri bermain.

Menurut Musfiroh (2005, 15) bermain memiliki arti yang penting, yaitu: (1) Bermain membantu anak membangun konsep dan pengetahuan; (2) Bermain membantu anak mengembangkan kemampuan mengorganisasi dan menyelesaikan masalah; (3) Bermain membantu anak mengembangkan kemampuan berpikir abstrak; (4) Bermain mendorong anak untuk berpikir kreatif; (5) Bermain meningkatkan kompetensi sosial anak; (6) Bermain membantu anak mengekepresikan dan mengurangi rasa takut; (7) Bermain membatu anak menguasai konflik dan trauma sosial; (8) Bermain membantu anak mengenali diri mereka sendiri; (8) Bermain membantu anak mengontrol gerak motorik; (9) Bermain membatu anak meningkatkan kemampuan berkomunikasi; Bermain menyediakan konteks yang aman dan memotivasi anak belajar bahasa kedua.

Bermain memiliki tujuan utama yakni memelihara perkembangan atau pertumbuhan optimal anak melalui 
Jurnal Warna : Jurnal Pendidikan Dan Pembelajaran Anak Usia dini. September 2017. Vol 02. No. 02

pendekatan bermain yang kreatif, interaktif dan terintegrasi dengan lingkungan bermain anak. Melalui kegiatan bermain anak mendapatkan pembelajaran yang mengandung aspek kognitif, sosial, emosi, dan fisik.

Salah satu tahap perkembangan anak yang senantiasa dikemas dalam pembelajaran akademik yaitu kognitif. Pengembangan kognitif dianggap sebagai aspek yang sangat penting sebagai bekal anak usia dini kejenjang pendidikan selanjutnya, sehingga cara pemberian stimulasi atau pembelajarannya terfokus pada ketercapaian anak dalam menguasai konsep. Pemberian stimulasi yang cenderung ke arah akademik menuntut anak untuk dapat mengerjakannya sesuai dengan apa yang menjadi prioritas pendidik. Tanpa disadari, anak-anak belajar dalam keadaan tertekan. Keadaan seperti ini tidak sesuai dengan kebutuhan anak yaitu belajar dalam lingkungan yang kondusif dan disesuaikan dengan taraf perkembangan anak.

Hansen and Kaufmann (dalam Vodopivec, 2011) menyebutkan bahwa pembelajaran kooperatif di Taman Kanak-Kanak untuk memberikan "feel good, develop creativity and a feeling of productivity, develop strategies for coping with life's problems, develop a feeling of happiness and belonging, learn new skills, have fun and laugh, relax, make mutual acquaintances and similar”. Hal tersebut akan memberikan dampak yang positif bagi anak, karena anak dapat mengembangkan kemampuannya dan memberikan pengalaman untuk belajar sesuatu dengan suasana yang menyenangkan.

Muatan makna yang ada di dalam pembelajaran kooperatif yaitu learning community, sharing ideas, diskusi, service learning, belajar kelompok, belajar konstektual, sumber belajar, problem-based learning, learning to be, learning to know, learning to do, learning to live together, task-based learning, school-based learning, dan ada collaborative learning (Nurhadi dalam Thobroni, 2015: 236). Berdasarkan muatan yang ada di dalam pembelajaran kooperatif tersebut, pembelajaran PAUD dikemas ke dalam bentuk permainan dengan tetap mengedepankan karakteristik anak.

Pembelajaran kooperatif dibagi menjadi beberapa jenis, yaitu student teams achievement division (STAD), jigsaw, investigasi kelompok (group investigation), make a match (membuat pasangan), teams games tournaments (TGT) (Rusman, 2012: 213-224). Beberapa model kooperatif tersebut dapat dikembangkan menjadi permainan yang disesuaikan dengan karakteristik anak usia dini. 
Jurnal Warna : Jurnal Pendidikan Dan Pembelajaran Anak Usia dini. September 2017. Vol 02. No. 02

Salah satu jenis tersebut adalah $\mathrm{s}$ make a match (membuat pasangan) yang dikembangkan oleh Lorna Curran memiliki keunggulan yaitu di dalam pelaksanaannya anak didik mencari pasangan sambil belajar mengenai suatu konsep atau sesuatu dalam suasana yang menyenangkan (Saputra dan Rudyanto, 2005: 69). Jenis ini dapat digunakan untuk semua aspek perkembangan anak usia dini. Penerapan make a match pada pembelajaran anak usia dini dapat dirancang melalui kegiatan bermain yang menyenangkan.

Pengembangan dari model make a match ini adalah permainan mahkota berteman. Permainan ini tidak hanya menggunakan media kartu, namun juga menggunakan mahkota yang terbuat dari kertas dengan diberi gambar konsep bilangan atau lambang bilangan yang sama dengan kartu. Permainan ini mengenalkan kepada anak tentang konsep bilangan dan lambang bilangan 1-10.

Permainan ini menuntut keaktifan anak untuk bergerak mencari pasangannya. Dua kelompok yang berbeda berada pada dua sisi yang berbeda, disaat harus mencari pasangannya masing-masing kelompok bergerak aktif di tengah. Ketika anak aktif bergerak di dalam permainan menandakan bahwa bahwa pikiran anak juga berfungsi.
Tujuan dari penelitian pengembangan ini adalah:

1. Menghasilkan permainan mahkota berteman yang layak digunakan untuk pembelajaran mengenalkan konsep dan lambang bilangan pada anak usia dini.

2. Meningkatkan kemampuan anak usia dini dalam mengenal konsep dan lambang bilangan.

\section{METODE PENELITIAN}

Penelitian ini dilakukan untuk menghasilkan produk berupa permainan yang bertujuan untuk mengenalkan konsep dan lambang bilangan pada anak usia dini. Untuk mengembangkan permainan mahkota berteman, peneliti menggunakan model pengembangan Dick and Carey (2011). Pemilihan model pengembangan Dick and Carey ini didasari oleh pandangannya tentang desain pembelajaran sebagai sebuah sistem dan menganggap pembelajaran adalah proses yang sitematis. Produk yang akan dihasilkan telah benar-benar mengikuti tahapan pengembangan untuk menghasilkan produk pembelajaran yang memiliki kelayakan.

Tahap evaluasi Dick and Carey, terdiri dari beberapa tahap, yaitu: validasi ahli, uji coba perorangan, uji coba kelompok kecil, dan uji coba lapangan. Dengan melewati tahapan- 
Jurnal Warna : Jurnal Pendidikan Dan Pembelajaran Anak Usia dini. September 2017. Vol 02. No. 02

tahapan tersebut, maka produk yang dihasilkan akan menjadi unggul.

Sepuluh langkah pengembangan tersebut pada gambar bagan sebagai berikut:

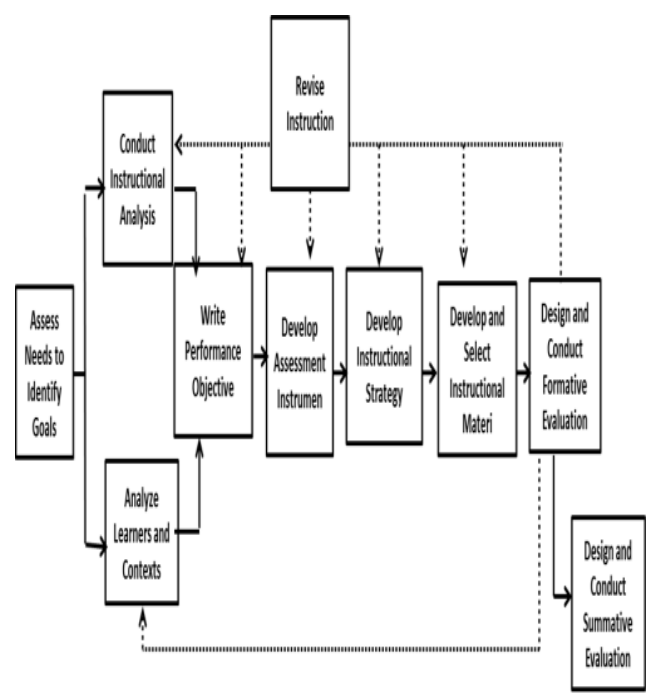

Gambar 1 Bagan Model Dick and Carey

(2001)

Uji coba lapangan dilakukan pada kelas yang sama (a regular-size class of learners). Sehingga, produk yang dihasilkan benar-benar digunakan untuk memecahkan permasalahan pembelajaran pada kelas yang bersangkutan.

Tahap revisi pembelajaran tidak hanya terbatas pada rancangan produk yang dihasilkan tetapi berlaku pada keseluruhan tahap pengembangan yang telah dilewati yaitu, dari tahap pengembangan pertama hingga tahap kedelapan. Jadi, jika ada hal-hal yang kurang tepat dalam tahap pengembangan sebelumnya dapat diperbaiki oleh peneliti.

Tahapan model pengembangan sistem pembelajaran (Instructional Systems Develovment/ISD) Dick, Carey (2011) terdiri dari 10 tahapan, yaitu:

1. Analisis kebutuhan untuk menentukan tujuan (Asses need to identify goals)

2. Melakukan analisis pembelajaran (Conducting instructional analysis)

3. Menganalisis warga belajar dan lingkungannya (Analyzing learner and Contexts)

4. Merumuskan tujuan khusus (Writing performance objective)

5. Mengembangkan instrumen penilaian (Developing criterionreferenced test items)

6. Mengembangkan strategi pembelajaran (Developing instructional strategy)

7. Mengembangkan materi pembelajaran (Developing and selecting instructional materials)

8. Merancang \& Mengembangkan Evaluasi Formatif (Designing and conducting the formative evaluation of instruction)

9. Merevisi Pembelajaran (Revise Instruction)

10. Mengembangkan evaluasi sumatif (Designing and conducting summative evaluation)Subyek uji coba produk permainan mahkota 
Jurnal Warna : Jurnal Pendidikan Dan Pembelajaran Anak Usia dini. September 2017. Vol 02. No. 02

berteman adalah anak didik

kelompok A TK Gerbang Indah

Gadang Malang.

\section{Teknik Pengumpulan Data}

Jenis data yang diperoleh dari ahli validasi isi dan materi ini berupa data kuantitaf dan data kualitatif. Data kuantitatif diperoleh dari hasil instrumen yang diberikan kepada subjek uji coba (ahli media dan ahli materi/isi), sedangkan data kulitatif berupa saransaran perbaikan.

Jenis data yang diperoleh dari kelompok perorangan, kelompok kecil dan kelompok besar bersifat data kuantitatif yang akan dihitung dengan menggunakan rumus persentase.

\section{Teknik Analisis Data}

Pengolahan data hasil dari validasi ahli, uji coba perorangan, uji coba kelompok kecil, dan uji coba lapangan digunakan teknik analisis data sebagai berikut:

1. Analisis data validasi ahli

Analisis data tentang proses pengembangan permainan mahkota berteman dilakukan dengan mempertimbangkan masukan, komentar, dan saran-saran dari para ahli dengan menggunakan skala Guttman (deskriptif). Skala ini memberikan empat (4) pilihan jawaban yakni sangat sesuai, cukup sesuai, kurang sesuai, dan tidak sesuai disertai dengan saran revisi/komentar. Sehingga jawaban yang diberikan bersifat jelas (tegas) dan konsisten (Sugiyono, 2011: 96).

2. Analisis data uji perorangan dan kelompok kecil

Analisis data menggunakan deskriptif dan statistik deskriptif.

3. Analisis uji lapangan

Untuk mengetahui hasil uji lapangan, peneliti membandingkan hasil pretest dan postest. Hasil dari kedua uji tersebut, untuk mengetahui apakah permainan mahkota berteman memberikan konstribusi dalam kemampuan anak dalam membilang dan mengenal lambang bilangannya.

\section{HASIL DAN PEMBAHASAN}

Prosedur kegiatan pengembangan yang dilakukan mengikuti tahapan pengembangan model Dick and Carey dengan langkah-langkah sebagai berikut:

1. Analisis kebutuhan untuk menentukan tujuan umum (Asses need to identify goals)

Langkah pertama adalah mengidentifikasi permasalahan dengan diperlukannya pengembangan, sehingga dapat menentukan tujuan umum. Berdasarkan hasil observasi yang telah dilakukan, ditemukan kendala dalam 
membilang konsep benda dan mengenal lambang bilangan pada anak TK A. Adapun kendala yang menyebabkan tidak tercapainya tujuan pembelajaran tersebut ialah kegiatan pembelajaran yang dilakukan dalam nuansa formal, kegiatan lebih didominan pada lembar kerja saja.

Berkaitan dengan permasalahan yang diuraikan di atas, dipandang perlu cara yang dapat membantu anak didik dalam memberikan solusi tersebut. Salah satu bentuk solusi adalah pengembangan permainan mahkota berteman. Produk tersebut diharapkan anak dapat membilang dan mengenal lambang bilangan dengan nuansa yang menyenangkan dan sesuai dengan karakteristik serta kebutuhan anak. Selain itu, permainan tersebut diharapkan dapat memberikan konstribusi dalam pembelajaran berhitung untuk anak usia dini sesuai dengan tahap perkembangan.

Berdasarkan analisis kebutuhan yang diuraikan di atas dan pertimbangan bahwa pembelajaran membilang untuk anak usia dini ditekankan pada pengenalan dengan melakukan aktivitas yang menuntut anak untuk aktif dalam mengenal konsep dan lambang bilangan. Maka, tujuan pembelajaran umum membilang untuk anak usia dini atau yang dikenal dengan istilah tingkat pencapaian perkembangan (TPP) ialah mengenal konsep dan lambang bilangan, yang tertuang pada Permendikbud No. 137 Tahun 2014 yaitu mengenal konsep bilangan dan lambang bilangan

2. Melakukan analisis pembelajaran (Conducting instructional analysis)

Analisis keterampilan bawahan atau langkah-langkah yang diperlukan untuk mencapai tujuan pembelajaran umum tertuang di standar PAUD pada Permendikbud No. 137 Tahun 2014. Berikut ini adalah indikator kegiatan dalam mengenal konsep bilangan dan lambang bilangan, diantaranya : a) Mengenal konsep bilangan; b) Menyebutkan konsep bilangan; c) Mengenal lambang bilanga; dan d) Membilang sesuai dengan lambang bilangan.

3. Menganalisis karakteristik anak dan konteks pembelajaran (Analyzing learner and Contexts).

a. Karakteristik anak

Anak kelompok A yang menjadi subyek dalam penelitian ini berada pada rentang usia 4 sampai 5 tahun. Berdasarkan hasil wawancara dengan guru kelas diperoleh informasi bahwa anak kelompok A TK Gerbang Indah Gadang Kota Malang tersebut, merupakan anak-anak yang memiliki kemampuan sama, bukan anak yang berkebutuhan khusus. Anak TK Kelompok A juga merupakan anak-anak 
yang aktif dalam proses pembelajaran khususnya ketika diajak bercakap-cakap.

b. Konteks pembelajaran

Proses pembelajaran membilang dan mengenal lambang bilangan di TK Gerbang Indah Gadang Kota Malang, guru biasanya memperkenalkan konsep dengan menggunakan gambar melalui lembar kerja. Gambar disesuaikan dengan tema yang telah ditentukan. Gambar-gambar tersebut hanya dijelaskan bagaimana cara mengerjakannya dengan memberikan contoh, misal menarik garis antara konsep dengan lambang bilangan.

4. Merumuskan tujuan pembelajaran khusus (Writing performance objective)

Tertuang di Standar PAUD pada Permendikbud No. 137 Tahun 2014 tujuan pembelajaran khusus dikenal dengan istilah indikator pembelajaran. Indikator pembelajaran dirumuskan berdasarkan pada tujuan instruksional umum dan analisis pembelajaran yang telah didapatkan. Berdasarkan pada tujuan pembelajaran umum dan analisis pembelajaran yang telah didapatkan sebelumnya maka tujuan instruksional khusus atau indikator pembelajaran membilang dan mengenal lambang bilangan untuk anak usia dini, sebagai berikut ini: a. Melalui permainan mahkota berteman, anak dapat mengenal konsep bilangan.

b. Melalui permainan mahkota berteman, anak dapat membilang sesuai dengan lambang bilangan (110).

c. Melalui permainan mahkota berteman, anak dapat mengenal lambang bilangan (1-10) sesuai dengan jumlah benda.

d. Melalui permainan mahkota berteman, anak dapat menghubungkan lambang bilangan dengan konsep bilangan.

e. Melalui permainan mahkota berteman, anak dapat bekerjasama dalam membilang.

Agar hasil analisis capaian perkembangan dan indikator pembelajaran yang telah dipaparkan di atas dapat lebih jelas akan dipaparkan dalam tabel 4.1 berikut ini:

\begin{tabular}{|c|c|}
\hline $\begin{array}{c}\text { Capaian } \\
\text { Perkembangan } \\
\end{array}$ & Indikator Pembelajaran \\
\hline \multirow{2}{*}{$\begin{array}{l}\text { Melakukan kegiatan } \\
\text { yang menunjukkan } \\
\text { anak mampu } \\
\text { mengenal benda } \\
\text { dengan } \\
\text { memasangkan benda } \\
\text { sesuai pasangannya }\end{array}$} & $\begin{array}{l}\text { 1. Mencocokkan } \\
\text { lambang bilangan } \\
\text { dengan } \\
\text { bilangan }\end{array}$ \\
\hline & \begin{tabular}{ll} 
2. & \multicolumn{2}{l}{ Menghubungkan } \\
konsep & bilangan \\
dengan & lambang \\
bilangan &
\end{tabular} \\
\hline $\begin{array}{l}\text { Menghubungkan } \\
\text { benda-benda } \\
\text { konkret dengan } \\
\text { lambang bilangan 1- } \\
10\end{array}$ & $\begin{array}{l}\text { 1. Membilang dengan } \\
\text { benda sesuai dengan } \\
\text { lambang bilangan }\end{array}$ \\
\hline
\end{tabular}

5. Mengembangkan Instrumen Penilaian (Developing criterionreferenced test items) 
Jurnal Warna : Jurnal Pendidikan Dan Pembelajaran Anak Usia dini. September 2017. Vol 02. No. 02

Tahap ini bertujuan untuk mengukur kemampuan anak dalam mengenal konsep bilangan dan lambang bilangan. Penilaian akan dilakukan oleh peneliti sebelum (pretest) dan sesudah (posttest) menggunakan permainan mahkota berteman yang telah dikembangkan. Instrumen penilaian sebelum dan sesudah penggunaan permainan mahkota tersebut dirancang dengan berpedoman pada kurikulum PAUD yang dikeluarkan oleh Kemendikbud tahun 2014.

6. Mengembangkan Strategi Pembelajaran (Developing instructional strategy)

Strategi pembelajaran yang dikembangkan dalam mengenal konsep dan lambang bilangan adalah melalui kegiatan permainan mahkota berteman. Pembelajaran dengan strategi pembelajaran ini, menitikberatkan pada kegiatan bermain yang akan mengajak anak untuk mengenal konsep dan lambang bilangan secara aktif (active learning) dan menyenangkan. Berikut ini adalah langkah-langkah permainan tersebut:

a. Guru mengajak anak-anak untuk bercakap-cakap tentang aktivitas hari ini, yaitu mengenal bentukbentuk geometri.

b. Setelah kegiatan bercakap-cakap, guru menunjukkan mahkota yang bergambar bentuk-bentuk geometri dan mahkota yang bertuliskan lambang bilangan.

c. Guru juga menunjukkan kartu gambar bentuk geometri dan kartu lambang bilangan yang sama seperti pada mahkota, mahkota lambang bilangan dan kartu lambang bilangan.

d. Anak-anak diajak untuk menghitung jumlah gambar yang ada di mahkota.

e. Guru menjelaskan dan mencontohkan cara permainan mahkota berteman.

f. Guru membagi anak dalam dua kelompok, yaitu kelompok gambar geometri dan kelompok lambang bilangan.

g. Kelompok gambar mendapatkan mahkota dan kartu bergambar geometri dengan jumlah yang sama dengan dimahkotanya. Kelompok kartu lambang bilangan mendapatkan mahkota dan kartu yang bertuliskan lambang bilangan.

h. Guru meminta masing-masing kelompok berada pada posisi yang berbeda, apabila guru sudah memberi tanda dengan membunyikan pluit, masing-masing kelompok bertemu menuju ke tengah untuk saling mencari pasangannya.

i. Anak yang memakai mahkota bergambar bentuk geometri yang 
Jurnal Warna : Jurnal Pendidikan Dan Pembelajaran Anak Usia dini. September 2017. Vol 02. No. 02

berjumlah lima, maka harus mencari pasangannya mahkota yang bertuliskan lambang bilangan lima. Apabila anak sudah menemukan pasangannya, maka harus mengucapkan yel-yel "kami berteman...yes".

j. Jika dalam waktu permainan yang ditentukan telah habis dengan ditandai bunyi pluit panjang, maka anak yang belum menemukan pasangannya diminta untuk menyampaikan jumlah gambar atau lambang bilangan berapa yang dibawanya, kemudian diminta untuk bernyanyi.

k. Jika sudah melalui satu putaran, masing-masing anak bergantian menjadi kelompok gambar geometri atau kelompok lambang bilangan.

7. Mengembangkan

Bahan Pembelajaran (Developing and selecting instructional materials)

Pembelajaran dalam mengenal konsep dan mengenal lambang bilangan yang dikembangkan berupa permainan mahkota berteman. Permainan yang dikembangkan dari model pembelajaran kooperatif make a match dengan menggunakan atribut mahkota yang diberi hiasan gambar bentuk-bentuk geometri dan lambang bilangan dan dilengkapi dengan kartu gambar bentuk geometri dan lambang bilangan.
8. Merancang \& Melaksanakan Evaluasi Formatif (Designing and conducting the formative evaluation of instruction)

Tahap ini menguji kelayakan permainan mahkota berteman digunakan empat tahap, yaitu validasi ahli (ahli materi dan ahli praktisi pembelajaran), uji coba perorangan, uji coba kelompok kecil, uji coba kelompok besar dan uji coba lapangan. Berikut ini hasil uji coba produk tersebut:

a. Validasi ahli materi PAUD

Validasi ahli materi dilakukan untuk menguji kelayakan media sebelum media ini digunakan untuk uji coba kelompok perorangan, kelompok kecil dan kelompok besar. Data yang diperoleh dari hasil validasi ahli berupa data kualitatif berbentuk komenter dan saran dimana data ini berupa angket dengan pilihan (1) belum sesuai secara keseluruhan, (2) sesuai namun belum secara keseluruhan, masih ada kekurangan pada kategori dan (3) sesuai dengan cakupan indikator.

Berdasarkan hasil validasi materi dari Bapak I Wayan Sutama, M.Pd. di atas pada indikator isi materi dan kemenarikan sudah sesuai dengan cakupan indikator. Ada empat indikator yang menunjukkan sesuai namun belum secara keseluruhan. Berdasarkan hasil catatan validator ahli materi tersebut, peneliti merevisi strategi pembelajaran 
yaitu penjelasan awal dititikberatkan pada pemahaman anak tentang konsep bilangan.

b. Validasi ahli praktisi pembelajaran PAUD

Berdasarkan hasil validasi dari Ibu Pangastutik, S.Pd. sebagai validator ahli praktisi pembelajaran yang tercantum pada tabel 4.4 di atas, dapat diketahui bahwa dari 16 indikator yang termuat menunjukkan 15 indikator yang sesuai dengan cakupan indikator. Hanya pada indikator dukungan permainan bagi kemandirian anak menunjukkan hasil validasi sesuai namun belum secara keseluruhan, masih ada kekurangan pada kategori.

Berdasarkan hasil catatan atau komentar dari validator yaitu dalam praktek permainan perlu pendampingan bagi anak-anak yang kurang aktif dan anak yang memiliki kemampuan di bawah rata-rata. Revisi yang dilakukan adalah pendampingan terutama pada anak-anak yang memiliki kemampuan dibawah rata-rata, serta anak yang kurang aktif saat melakukan permainan tersebut. Hal tersebut dimaksudkan agar saat anak melakukan permainan sesuai dengan strategi yang ditentukan.

c. Uji coba perorangan

Data hasil uji coba perorangan yang terdiri dari tiga anak didik Kelompok A2 TK Gerbang Indah tersebut di atas, diperoleh data bahwa semua indikator mendapat persentase $100 \%$. Berdasarkan hasil tersebut dapat disimpulkan bahwa produk pengembangan permainan berada pada kualifikasi sangat baik dan tidak perlu dilakukan perbaikan. Hasil uji coba menunjukkan langkah penggunaan yang diterapkan ke anak kurang dipahami, karena anak-anak hanya fokus pada kartu yang dibawa dan tidak melihat gambar atau lambang bilangan yang ada dimahkota temannya. Revisi yang dilakukan di awal lebih ditekankan bahwa antara kartu yang dibawa anak memiliki teman yang ada di mahkota temannya.

d. Uji Kelompok kecil

Setelah melewati tahap uji coba perorangan, selanjutnya dilakukan tahap uji coba kelompok kecil. Tahap ini diberikan kepada anak kelompok A TK Gerbang Indah Gadang yang berjumlah 7 orang anak dengan tujuan untuk mengetahui efektivitas perubahan hasil revisi pada tahap uji coba perorangan dan identifikasi terhadap permasalahan yang mungkin masih tersisa.

Berdasarkan hasil observasi pada uji coba kelompok kecil dapat diketahui bahwa hasil keseluruhan prosentase pada 7 (tujuh) responden adalah sebesar $87,3 \%$. Setelah dikonvensikan, tabel konvensi menunjukkan bahwa produk yang dikembangkan berada pada kualifikasi baik dan tidak perlu direvisi. 
e. Uji Kelompok besar

Tahap ini bertujuan untuk menggunakan produk yang dikembangkan dalam konteks pembelajaran yang sebenarnya dan untuk mengetahui pengaruhnya dalam memperkenalkan konsep berhitung pada anak. Berdasarkan hasil observasi pada uji coba lapangan dapat diketahui bahwa hasil keseluruhan persentase pada 15 (lima belas) responden adalah sebesar 91\%. Persentase itu menunjukkan bahwa permainan mahkota berteman menurut tabel konversi tingkat pencapaian berada pada kualifikasi sangat baik.

f. Uji coba lapangan

Untuk mengetahui pengaruh pengembangan permainan mahkota berteman yang telah dikembangkan terhadap kemampuan berhitung anak, maka peneliti memberikan perlakuan (pretest dan posttest) pada anak kelompok A TK Gerbang Indah Gadang Malang. Hal ini untuk mengetahui bagaimana pengetahuan anak sebelum dan sesudah mendapatkan pembelajaran dengan menggunakan permainan mahkota berteman.

Sebelum melakukan pengujian hipotesis dengan menggunakan uji t-test, peneliti perlu mengetahui normalitas data. Jika normalitas data terpenuhi maka t-test bisa digunakan. Adapun hasil uji normalitas pada tabel 4.12 berikut ini:
Tabel 4. 12 Hasil Uji Normalitas Data Pretest dan Posttest

One-Sample Kolmogorov-Smirnov Test

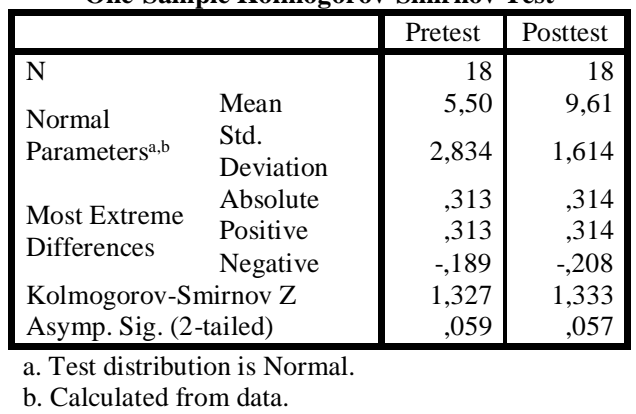

Berdasarkan tabel di atas dapat diketahui bahwa nilai Kolmogrov Smirnov memiliki signifikansi lebih besar dari 0,05 baik dari hasil sebelum perlakuan (pretest) dan sesudah perlakuan (posttest). Signifikansi sebelum perlakuan (pretest) menunjukkan hasil 0,059 dan signifikansi sesudah perlakuan (posttest) menunjukkan hasil 0,057. Sehingga dapat dikatakan bahwa hasil uji normalitas data pretest dan posttest berdistribusi normal.

Adapun hasil uji t-test pada tabel 1 berikut ini:

Tabel 1 Data Hasil Uji T-Test One-Sample Test

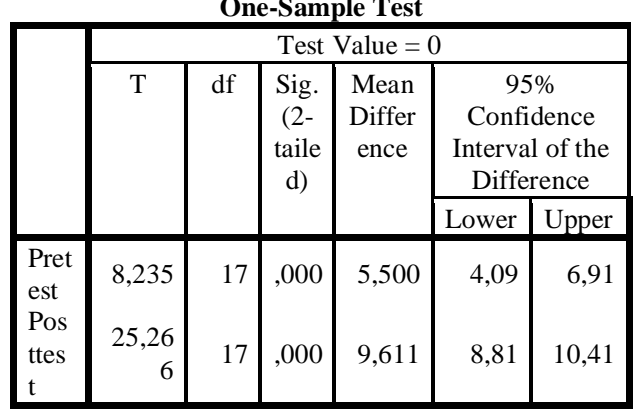

Berdasarkan uji t-test di atas, diketahui signifikansi yang diperoleh sebesar 0,000 yang berarti lebih kecil 
Jurnal Warna : Jurnal Pendidikan Dan Pembelajaran Anak Usia dini. September 2017. Vol 02. No. 02

dari pada signifikansi yang digunakan dalam penelitian ini yaitu 0,05 ( $\mathrm{sig}=$ $0,000<0,05) . \quad$ Berdasarkan hasil pengujian terhadap hipotesis dapat disimpulkan bahwa $\mathrm{H}_{0}$ di tolak dan $\mathrm{H}_{1}$ diterima. Sehingga dalam penelitian pengembangan ini dapat disimpulkan bahwa setelah menggunakan permainan mahkota berteman kemampuan anak dalam mengenal konsep dan lambang bilangan menjadi lebih baik.

\section{Revisi Instruksional}

(Revise Instruction).

Setelah semua uji coba dilaksanakan makadilakukan Revisi Instruksional yang dilaksanakan dalam 5 tahap yaitu (1) revisi dari ahli materi, (2) revisi dari ahli praktisi pembelajaran, (3) revisi dari uji coba perorangan, (4) revisi uji coba kelompok kecil dan (5) revisi uji coba kelompok besar. Yang nantinya revisi dilakukan sampai disetujui oleh masing-masing tahap. Jika masih belum disetujui maka akan terus dilakukan revisi agar permainan menjadi alat Instruksional lebih efektif.

10. Merancang \& melaksanakan evaluasi sumatif (Designing and conducting summative evaluation)

$$
\text { Pengembangan ini tidak }
$$

dilakukan evaluasi sumatif karena menurut Dick and Carey (2001: 8) langkah ke-10 ini bukan dari proses desain, karena tidak melibatkan perancang melainkan evaluator independen. Karena itu, dalam pengembangan ini tidak dilakukan evaluasi sumatif. langkah pengembangan hanya dilakukan sampai pada tahap ke-9 yaitu revisi desain produk pengembangan sehingga produk tersebut siap untuk dipakai.

\section{PENUTUP}

\section{Kesimpulan}

Berdasarkan hasil penelitian pengembangan di atas, maka dapat disimpulkan sebagai berikut:

1. Pengembangan permainan mahkota berteman melewati beberapa tahap yaitu tahap validasi ahli materi pembelajaran PAUD, validasi ahli praktisi pembelajaran PAUD, uji coba perorangan dan tahap uji coba kelompok kecil. Berdasarkan tahaptahap tersebut diperoleh data sebagai berikut:

a. Validasi ahli materi PAUD, pada tahap ini diperoleh data bahwa materi pembelajaran yang diberikan sudah sesuai, masukan dari validator adalah merevisi strategi pembelajaran yaitu penjelasan awal dititikberatkan pada pemahaman anak tentang konsep bilangan. Pengenalan selanjutnya baru pada konsep lambang bilangan. Revisi juga pada mahkota yaitu tali pengikat yang sebelumnya adalah 
pita diganti dengan karet elastis, sehingga anak mudah memakainya.

b. Validasi ahli praktisi pembelajaran PAUD, pada tahap ini diperoleh data bahwa satu indikator pada variabel kemandirian dalam mengimplementasi permainan. Masukan yang diberikan yaitu perlu pendampingan bagi anak-anak yang kurang aktif dan anak yang memiliki kemampuan di bawah rata-rata. Hal tersebut dimaksudkan agar saat anak melakukan permainan sesuai dengan strategi yang ditentukan.

c. Pada uji coba perorangan yang diberikan pada tiga orang anak, data diperoleh dari instrumen pedoman observasi. Persentase hasil observasi sebesar 100\%, yang berarti produk sudah layak untuk diujicobakan pada tahap uji coba kelompok kecil. Hasil tersebut menunjukkan bahwa semua langkah permainan dapat dimainkan oleh anak-anak dengan baik.

d. Pada uji coba kelompok kecil yang diberikan ada tujuh anak, data diperoleh dari instrument pedoman observasi. Hasil yang diperoleh menunjukkan sebesar $87,3 \%$ yang berarti produk sudah layak untuk diujicobakan pada tahap uji coba lapangan. Demikian pula dari hasil observasi diperoleh data bahwa semua langkah permainan dapat dimainkan oleh anak-anak dengan baik.

2. Hasil uji coba lapangan, data yang diperoleh dari pre-test dan post-test dihitung dengan menggunakan software SPSS 20. Dari perhitungan tersebut didapatkan nilai signifikansi 0,00 yang berarti lebih kecil dari pada signifikansi yang digunakan dalam penelitian ini yaitu 0,05 , maka $\mathrm{H}_{0}$ di tolak dan $\mathrm{H}_{\mathrm{a}}$ diterima. Dengan demikian, dapat disimpulkan bahwa permainan mahkota berteman dapat meningkatkan kemampuan mengenal konsep dan lambang bilangan pada anak usia dini.

\section{Saran}

Berdasarkan hasil dari pengembangan permainan mahkota berteman, selanjutnya disampaikan saran-saran berikut ini:

\section{Guru PAUD}

Secara teoritis permainan "mahkota Berteman' dapat digunakan untuk mengembangkan kemampuan mengenal konsep dan lambang bilangan.Untuk itu para guru TK/RA disarankan menerapkan permainan tersebut untuk mengembangkan kemampuan anak.

2. Lembaga PAUD 
Kegiatan permainan yang dilakukan anak dengan baik berdampak pada tujuan tercapainya tujuan yaitu terjadinya perkembangan pada anak.. Berkenaan dengan hal tersebut maka disarankan kepada lembaga untuk senantiasa melakukan pembelajaran dengan menggunakan pendekatan yang berprinsip pada pembelajaran anak usia dini yaitu belajar sambil bermain. Melakukan pengembangan pembelajaran dengan selalu berinovasi mennciptakan permainan yang menarik minat anak untuk mendukung aspek perkembangan anak.

\section{DAFTAR PUSTAKA}

Aisyah, dkk. 2015. Pembaharuan Pendidikan TK. Jakarta: Universitas Terbuka.

Departemen Pendidikan Nasional. 2014. Peraturan Pemerintah No. 137 Tentang Standar Nasional Pendidikan Anak Usia Dini. Jakarta: Depertemen Pendidikan Nasional.

Dick, W., Lou C. dan James O.C. 2001. The Systematic Design of Instruction. London: Pearson.

Musfiroh, T. 2005. Bermain Sambil Belajar dan mengasah Kecerdasan. Jakarta: Departemen pendidikan Nasional.

Mutiah, D. 2010. Psikologi Bermian Anak Usia Dini. Jakarta: Kencana Prenada Media Group.

Rusman. 2012. Model-Model Pembelajaran Mengembangkan Profesionalisme
Guru. Jakarta: PT. RajaGrafindo Persada.

Saputra, Y.M. dan Rudyanto. 2005. Pembelajaran Kooperatif untuk Meningkatkan Keterampilan Anak TK. Jakarta: Departemen pendidikan Nasional.

Semiawan, C.R. 2008. Belajar dan Pembelajaran Prasekolah dan Sekolah Dasar. Jakarta: PT. Indeks.

Sugiyono. 2011. Metode Penelitian Pendidikan Pendekatan Kuantitatif, Kualitatif, dan $R \& D$. Bandung: Penerbit Alfabeta.

Sugiono dan Kuntjojo. 2016. Pengembangan Model Permainan Pra-Calistung Anak Usia Dini. JURNAL PENDIDIKAN USIA DINI Volume 10 Edisi 2, November 2016.

Sujiono, Y.N. 2012. Konsep Pendidikan Anak Usia Dini. Jakarta: PT. Indeks

Sukardi, M. dkk. 2012. Pengembangan Materi Bidang Studi Pendidikan Anak Usia Dini. Malang: Universitas Negeri Malang.

Suparno, P. 2001. Teori Perkembangan Kognitif Jean Piaget. Yogyakarta: Kanisius.

Susanto, A. 2012. Perkembangan Anak Usia Dini. Jakarta: Kencana Prenada Media Group.

White, R. E. 2012. The Power of Play: A Research Summary on Play and Learning. St. Paul: MCM. 